\title{
Growth and contractility of cells from fibrocellular epiretinal membranes in primary tissue culture
}

\author{
D Y JIANG,' P S HISCOTT, ${ }^{2}$ I GRIERSON,' AND D MCLEOD \\ From the 'Department of Pathology, Institute of Ophthalmology, London, and the 'Surgical Vitreoretinal \\ Unit, Moorfields Eye Hospital, London
}

SUMmaRY Cells grew out in tissue culture from 37 of 53 fibrocellular epiretinal membrane explants, those from membranes of less than four months' clinical duration growing more consistently, more rapidly, and more exuberantly than those from membranes of more than four months' clinical duration. Electron microscopy demonstrated prominent microfilaments in the cytoplasm of some of the cells, and immunostaining for actin showed great variations in the pattern and intensity of staining. An ATP contraction assay conducted on 44 detergent-extracted cells and 47 intact cells revealed in each case a $30 \%$ average reduction in cell area. Immunostaining for cytokeratins following the ATP assay showed no significant difference in cell contraction between epithelial cells and non-epithelial cells. Clinical duration of the membrane had no significant influence on the contractility of cells growing from the explant.

Contractile epiretinal membranes (ERMs) cause distortion and detachment of the retina in such diverse clinical settings as ocular trauma, ischaemia, and inflammation, but they are particularly extensive and destructive of vision when complicating the treatment of rhegmatogenous retinal detachmentso-called proliferative vitreoretinopathy (PVR). The cellular components of ERMs are also diverse even within ERMs of similar aetiology. In PVR, for example, morphological and immunohistochemical investigations of surgically excised ERMs have demonstrated macrophages, fibroblasts, glial cells, and pigment epithelial cells..$^{1-5}$ All these cell types grow out from explants of ERMs in tissue culture, ${ }^{-6-8}$ though the proportions of cells in culture presumably reflect not only the initial cell composition of the ERM but also the relative viability, proliferative capacity, and migratory activities of cells together with the effects of preferential growth (selection) within any particular tissue culture medium. A recent report from our laboratory demonstrated a significant difference in the cellular composition and collagen content of excised ERMs according to clinical ERM duration, ${ }^{,}$and this study seeks to determine, firstly, whether such differences are reflected in the growth characteristics of ERMs in tissue culture.

Correspondence to Dr I Grierson, Pathology Department, Institute of Ophthalmology, 17-25 Cayton Street, London EC1V 9AT.
Contraction of ERMs is thought to be a cell mediated event akin to that seen in skin wounds and granulation tissue. ${ }^{11} 11$ The scar tissue fibroblasts have been called 'myofibroblasts' because of the prominence of contractile elements within their cytoplasm. Assuming that cells responsible for ERM contraction (or their immediate progeny) are represented among those cells growing out from our ERM explants in primary tissue culture, we have also investigated their cytoplasmic contractile elements by electron microscopy and immunostaining for actin, and have monitored the contractility of individual cells in response to adenosine triphosphate (ATP). We further investigated (1) whether prior detergent treatment of cells was necessary in order to demonstrate contractility, (2) whether the clinical age of the ERM affected contractility, and (3) whether any difference in contractility could be demonstrated between epithelial cells (indicated by antiprekeratin immunostaining $)^{5}$ and other cells in the cultures, since pigment epithelial cells have been especially implicated in PVR. ${ }^{2}$

\section{Materials and methods}

TISSUE CULTURE

A total of 53 fibrocellular ERMs were obtained for tissue culture during closed vitrectomy procedures. The ERMs were associated with a variety of condi- 
Table 1 Aetiology of ERMs

\begin{tabular}{|c|c|c|c|c|}
\hline & \multirow{2}{*}{$\begin{array}{l}\text { Number of } \\
\text { ERMs }\end{array}$} & \multicolumn{2}{|c|}{ Clinical duration } & \multirow{2}{*}{$\begin{array}{l}\text { Outgrowth } \\
\text { within } 4 \\
\text { weeks }\end{array}$} \\
\hline & & Early & Late & \\
\hline PVR & 34 & 20 & 14 & 26 \\
\hline Trauma & 7 & 4 & 3 & 6 \\
\hline Vascular occlusion & 3 & 0 & 3 & 1 \\
\hline Others & 9 & 2 & 7 & 4 \\
\hline Total & 53 & 26 & 27 & 37 \\
\hline
\end{tabular}

$\mathrm{PVR}=$ proliferative vitreoretinopathy.

tions and were subgrouped into those of less than four months' clinical duration ('early' membranes) and those of four months' duration or longer ('late' membranes) (Table 1). Of the 53 ERMs 26 were the subject of an earlier preliminary communication.'

The segments of membrane (explants) were settled on the base of $25 \mathrm{~cm}$ Falcon flasks and held in place by overlying coverslips and fed with culture medium. The medium consisted of $10 \%$ fetal calf serum (Gibco), 10\% newborn calf serum (Gibco) in 199 medium (Gibco). Cultures were maintained at $37^{\circ} \mathrm{C}$ in an atmosphere of $5 \% \mathrm{CO}_{2}$ and air with $100 \%$ humidity (Leec incubators). All cultures were examined routinely with an inverted phase microscope (Olympus) and refed once a week. If the explants did not develop a cellular outgrowth within four weeks, the culture was considered non-viable and abandoned. For all viable cultures the time taken before the first cells migrated from the explant (latent period) was recorded. Subsequent growth in primary culture was classified into three stages: stage 1 was a patchy outgrowth involving less than 50 cells; stage 2 was a more uniform cellular spread involving more than 50 cells (Fig. 1); while stage 3 was a packed culture (Fig. 2). The present study was restricted to primary cultures because it was considered that such cells might be more akin to cells 'in situ' than cells cultured through one or more passages.

TRANSMISSION ELECTRON MICROSCOPY (TEM)

If a membrane was sufficiently large, a portion was taken for TEM while the remainder served as an explant for tissue culture. In addition, some membranes with their resultant outgrowth of cells were processed from culture for TEM. All specimens were fixed with $3 \%$ glutaraldehyde in cacodylate buffer, postfixed in $1 \%$ buffered osmium tetroxide, dehydrated through graded alcohols, and embedded in Araldite. Ultrathin sections were stained with uranyl acetate and lead citrate and viewed in a JEOL 100c electron microscope.

\section{ATP ASSAY}

Ninety-one cells growing on coverslips from 13 ERMs (from two to 27 cells from each membrane) were assayed. The majority of cells to be assayed grew from ERM explants of specimens from eyes with PVR. Forty-eight cells grew from seven early ERMs and 43 cells from six late ERMs. The cells were washed in phosphate buffered saline (PBS) and then 44 cells from seven membranes (both early and late) were exposed to $0 \cdot 2 \%$ Triton X-100 in stabilisation buffer for two minutes at room temperature; the other 47 cells from six ERMs were not so treated. The stabilisation buffer consisted of $0.01 \mathrm{M}$ Tris- $\mathrm{HCl}(\mathrm{pH}$ 7.6), $0.14 \mathrm{M} \mathrm{NaCl}, 0.005 \mathrm{M} \mathrm{MgCl}_{2}$, and $4 \%$ poly-

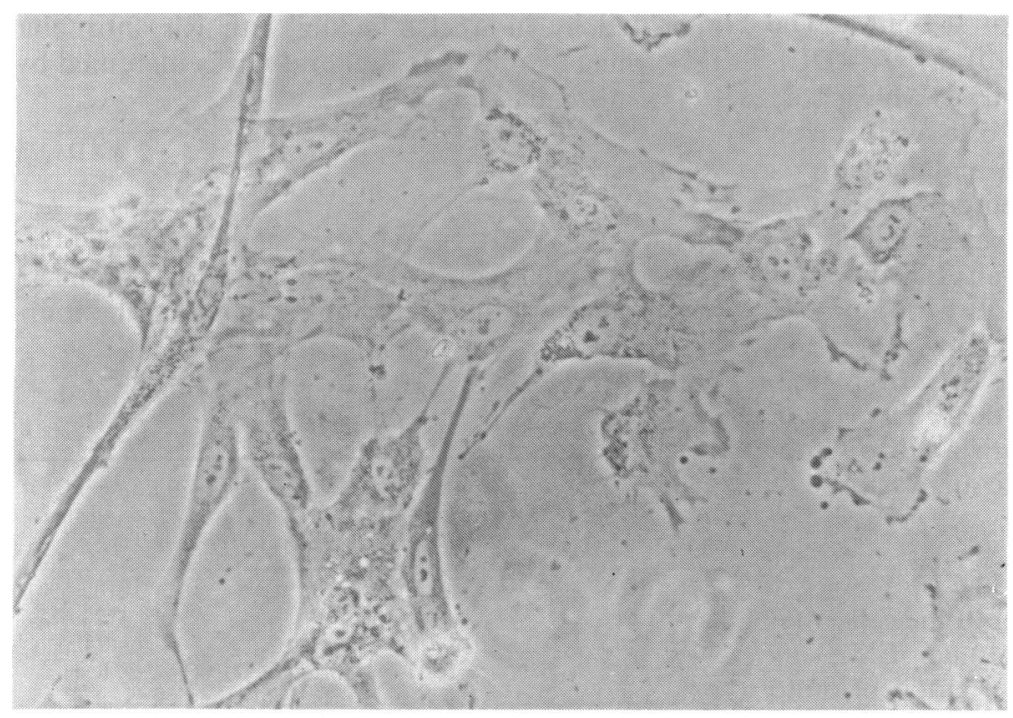

Fig. 1 Cells growing out from an ERM explant have reached stage II. $\times 550$. 
Fig. 2 Cells from an ERM approaching confluence. $\times 300$.

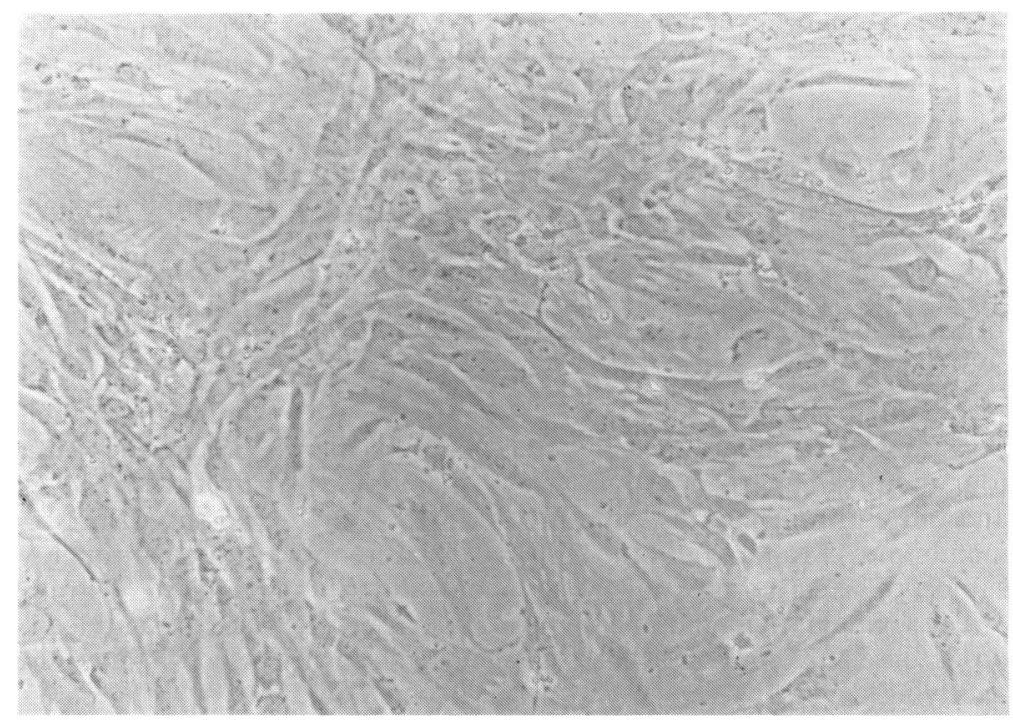

ethylene glycol 6000 . This is thought to preserve much of the intracellular contractile filament system while allowing the detergent to open up the cell for easy penetration of ATP. ${ }^{12}$ Those cells which went through the detergent extraction process were washed in PBS.

Thereafter the detergent treated cells and untreated cells on coverslips were placed on the heated stage $\left(37^{\circ} \mathrm{C}\right)$ of an inverted phase microscope (Olympus). Individual cells or multiple discrete cells which had clear outlines were selected, located, and centralised with a $\times 20$ phase objective lens as soon as possible, and a photograph was taken of this field for further reference. Without altering the field the PBS was replaced with contraction buffer, to which was added ATP to a concentration of $0.1 \mathrm{mM}$. The contraction buffer consisted of $0.01 \mathrm{M}$ Tris- $\mathrm{HCl}$, $0.03 \mathrm{M} \mathrm{KCl}, 10 \mu \mathrm{m} \mathrm{CaCl}$, and $0.005 \mathrm{M} \mathrm{MgCl}_{2}(\mathrm{pH}$ 7.0). Photographs of the selected cells were taken every minute for the first 10 minutes and thereafter a photograph was taken every 10 minutes up to one hour. Thus a total of 16 negatives were available for each cell from each experimental 'run'. The film was passed through a film reader (Zeiss) with a $\times 17.5$ objective lens and projected on to an upright screen. The outline of each cell was drawn at various time periods during the run. The area of the cells was then measured by outlining the cell with a cursor integrated with a semiautomated image analysis system (MOP Videoplan, Kontron).

\section{IMMUNOSTAIN ING}

Coverslips of cultured ERM cells or of the cells after undergoing Triton X-100 treatment and/or MgATP assay were washed in PBS and air dried prior to indirect immunofluorescence staining, which was conducted according to procedures outlined in previous publications. ${ }^{47}$ The primary antibody used for identification of epithelial cells was antiprekeratin raised in guinea-pigs (Miles Scientific) and for demonstration of actin was antiactin raised in rabbits (Dako Corporation). The second antibodies were fluorescein isothiocyanate (FITC) conjugated goat antirabbit IgG, FITC conjugated goat antiguinea-pig IgG and tetramethylrhodamine isothiocyanate $(\mathrm{Rh})$ conjugated goat antirabbit IgG. For such single labelling investigations FITC antispecies IgG was used to demonstrate the primary antibody. In addition, double labelling studies were conducted on non-assayed cells in which cytoplasmic actin was indicated by indirect labelling with $\mathrm{Rh}$ antirabbit $\mathrm{IgG}$, while cytoplasmic prekeratin was identified by FITC anti-guinea-pig IgG.

\section{Results}

GROWTH CHARACTERISTICS AND FEATURES Under the conditions of culture outlined 37 of the 53 membranes produced an outgrowth within the four-

Table 2 Growth characteristics of ERMs in primary tissue culture

\begin{tabular}{lcllr}
\hline & $\begin{array}{l}\text { Number } \\
\text { of ERMs }\end{array}$ & $\begin{array}{l}\text { Outgrowth } \\
\text { within 4 } \\
\text { weeks }\end{array}$ & $\begin{array}{l}\text { Mean latent period } \\
\text { indays } \\
( \pm \text { standard error) }\end{array}$ & $\begin{array}{l}\text { Stage III } \\
\text { outgrowths }\end{array}$ \\
\hline Early ERMs & 26 & $23(88.5 \%)$ & $2 \cdot 67 \pm 0 \cdot 3$ & $16(69.5 \%)$ \\
Late ERMs & 27 & $14(51 \cdot 9 \%)$ & $5 \cdot 79 \pm 0 \cdot 5$ & $4(28 \cdot 6 \%)$ \\
Early vs late & & $\begin{array}{l}\mathrm{p}<0 \cdot 01 \\
\left(\chi^{2} \text { test }\right)\end{array}$ & $\begin{array}{l}\mathrm{p}<0 \cdot 01 \\
(\text { Student's } t \text { test })\end{array}$ & $\begin{array}{l}\mathrm{p}<0 \cdot 05 \\
\left(\chi^{2} \text { test }\right)\end{array}$ \\
\hline
\end{tabular}




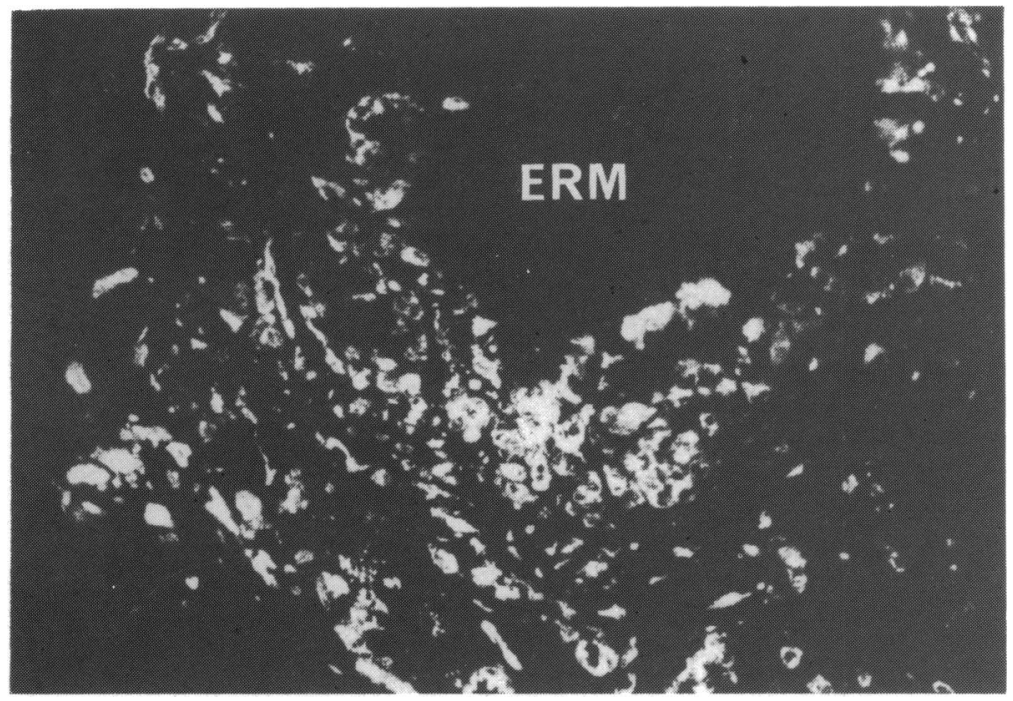

Fig. 3 Antiactin indirect immunostaining with $R h$ conjugated to the second antibody of a cellular outgrowth from an epiretinal membrane (ERM) showing variable actin staining. The ERM does not fluoresce and therefore cannot be seen. $\times 100$.

week period (Table 2). The cells which grew from the ERMs were of variable appearance including spindle-shaped, plate-like, stellate, and ovoid cells (Fig. 1). There was a statistically significant difference between early and late ERMs in respect of viability (i.e., the numbers of explants yielding cells), latency (i.e., the time period prior to outgrowth of cells), and exuberance ' of outgrowth (i.e., the numbers of explants producing packed or stage 3 cultures) (Table 2).

\section{IMMUNOHISTOCHEMISTRY AND TEM}

Antiactin immunostaining highlighted the presence of contractile proteins within the ERM cells growing in tissue culture (Fig. 3). There was variability in the intensity of staining (Fig. 3) and in the pattern of staining, which was either reticular or diffuse (Fig. 4A, B). There was no pronounced reduction in antiactin staining after detergent treatment, and cytoplasmic actin was still prominent following exposure to ATP, though the staining pattern was always diffuse.

Among the growing cells antiprekeratin immunostaining showed the presence of epithelial cells interspersed between non-epithelial cells (Fig. 5). Double immunostaining illustrated cytoplasmic actin in both prekeratin-positive and prekeratin-negative cells, with no demonstrable difference between these cell types (Fig. 6A). Closer examination of cells which stained positively with both antisera revealed a difference in the distribution of the two antigens; the actin-rich elements were spread throughout the cytoplasm, whereas prekeratin was concentrated around the cell nucleus (Fig. 6B).

Electron microscopy confirmed the presence of
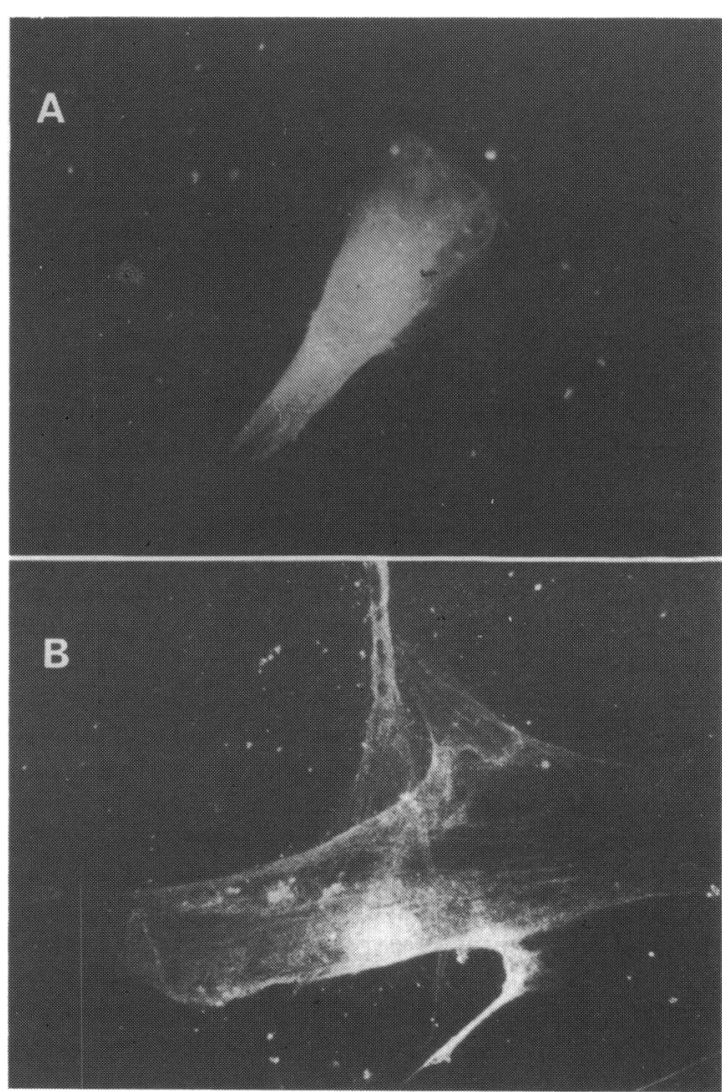

Fig. 4 A diffuse pattern of actin is seen in the cytoplasm of a cultured ERM cell (A) whereas the pattern is reticular in another cell (B) (FITC). $\times 600$. 
Fig. 5 Positive (arrows) and negative (arrowheads) cells in an antiprekeratin (FITC). $\times 400$. ERM culture after staining with

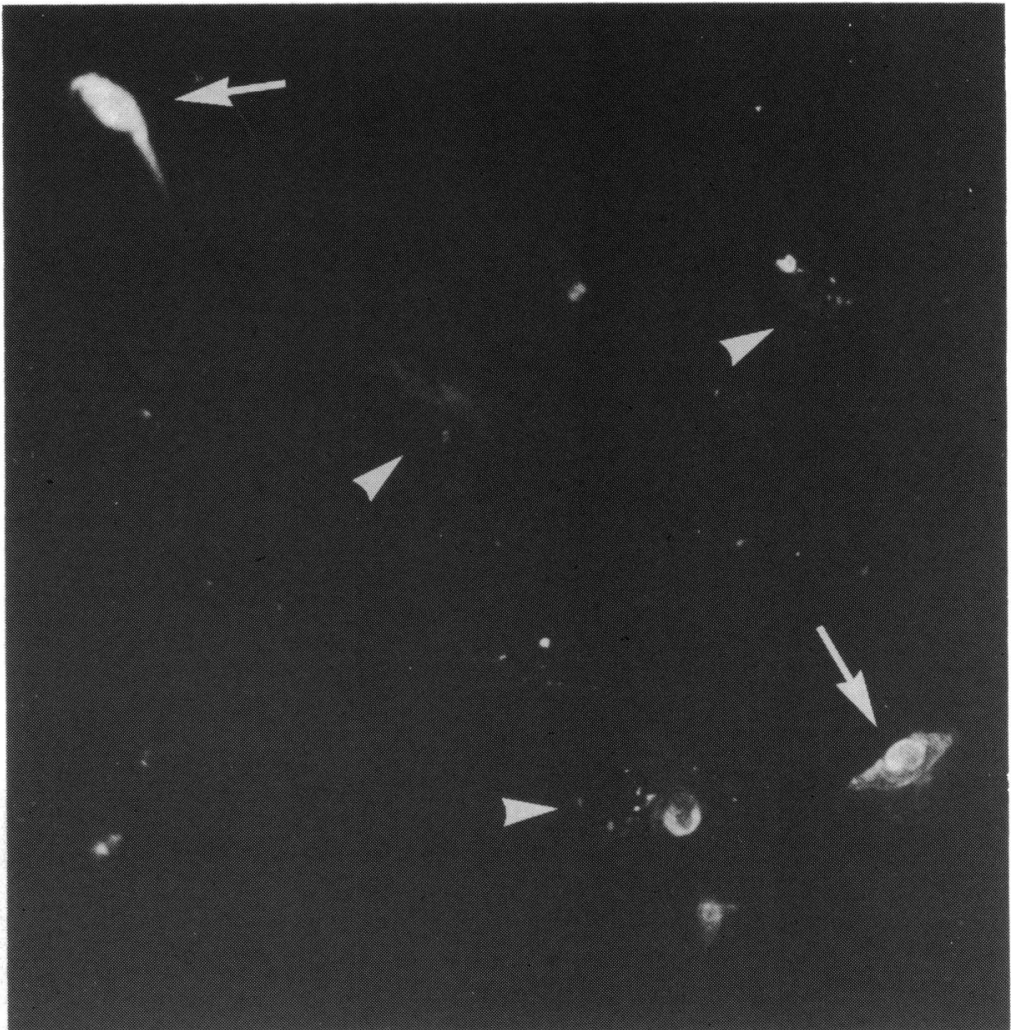

cytoplasmic microfilaments (4-6 $\mathrm{nm}$ in diameter) in the cytoplasm of cells both within the ERM explant (Fig. 7) and growing in the culture flask. Microfilaments were abundant in some cells but difficult to find in others.

\section{ATP ASSAY}

The MgATP assay was more easily conducted on intact cells than on detergent treated cells because cell outlines could be seen more clearly (Fig. 8). Each of the $\mathbf{4 4}$ detergent treated cells had a reduced surface area after one hour's exposure to ATP, but there was marked variation in response between cells, ranging from as little as $7 \%$ to as much as $66 \%$ (Fig. 9 ). The mean area reduction was approximately $30 \%$ and significant by the paired $t$ test $(\mathrm{p}<0.001)$ (Table 3 ). Most of the reduction in surface area took place in the first 10 minutes of exposure to ATP (Fig. 10A, B). Of these 44 detergent treated cells 26 were prekeratin positive (Fig. 11), 11 were prekeratin negative and seven could not be identified after ATP assay because they were washed off during processing for indirect immunostaining. Table 3 also shows that the decrease in surface area after one hour was not significantly different in the three groups (i.e., in prekeratin-positive cells, prekeratinnegative cells, and unidentified cells) by Student's $t$ test. The response of individual cells to ATP was as inconsistent in the prekeratin-positive group as it was for the whole series of cells (ranging from $7 \%$ to $50 \%$ reduction in area).

Of the 47 cells exposed to ATP without prior treatment with detergent (i.e., intact cells) all but one responded with a decrease in surface area (Fig. 12). Over a one-hour period the response was again variable (ranging from $-1 \%$ to $65 \%$ with a mean of $34 \%$ ), and most of the reduction once again took place in the first 10 minutes (Fig. 10A). The reduction in area was significant by the paired $t$ test (Table 4) but was not significantly different from the reduction in area recorded from detergent treated cells ( $t$ test). Of these 47 intact cells, 18 were prekeratin-positive, nine were prekeratin-negative, and 20 could not be identified (Table 4). The decrease in area of the prekeratin-positive cells ranged from $-1 \%$ to $50 \%$, but there was no significant difference in the degree of response between prekeratin-positive, prekeratinegative, and unidentified cells (Table 4).

The average reduction in area of 48 cells from early membranes was $30 \%( \pm 1.9 \%)$ and of 43 cells from 

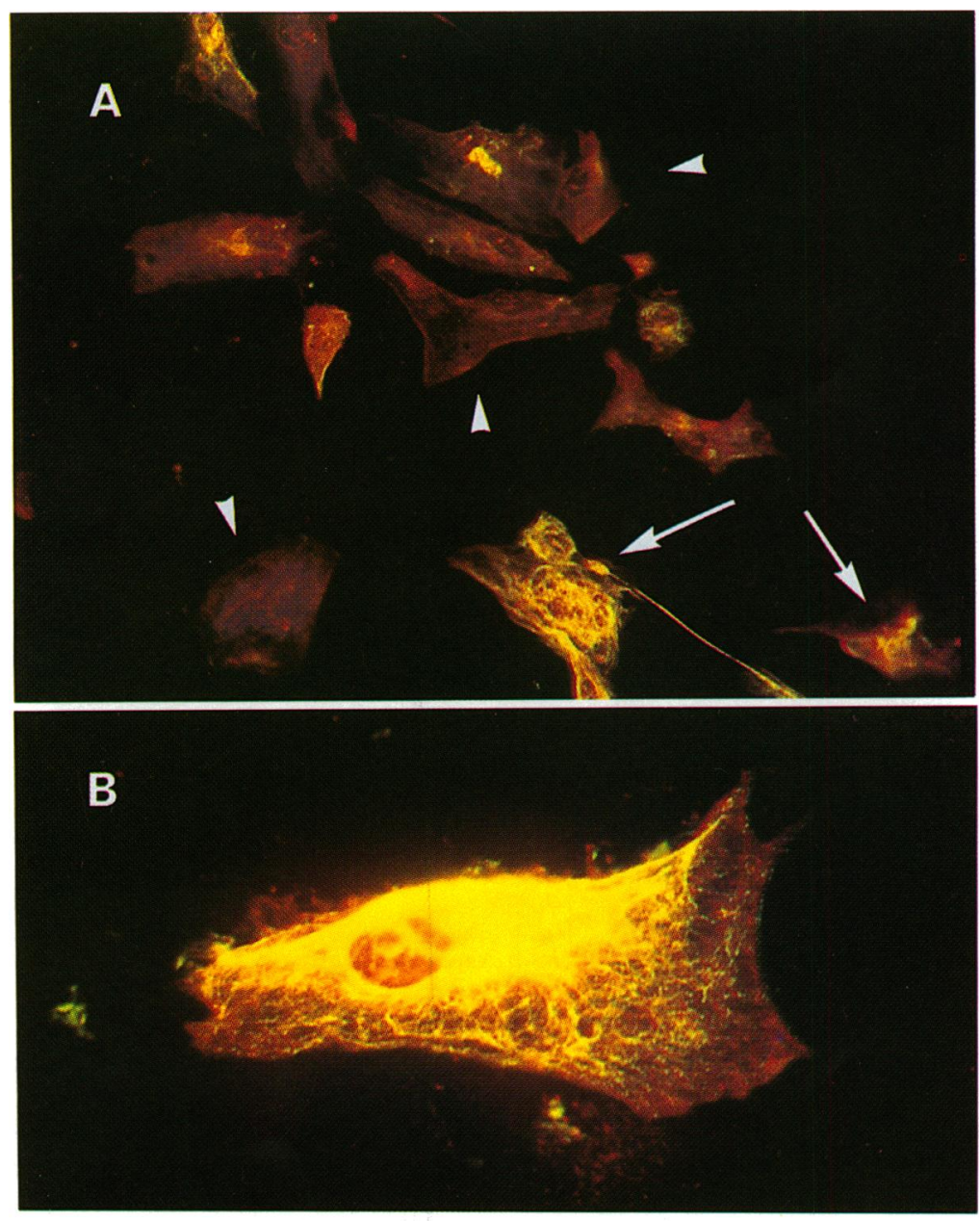

Fig. 6 Prekeratin (FITC, green) and actin $(R h$, red) double staining of an ERM culture. A: Prekeratinnegative cells (arrowheads) have a variable intensity of red. Prekeratin-positive cells (arrows) show some green, some red and also yellow where the prekeratin and actin fluorescence coincide $(\times 300)$. B: A prekeratin-positive cell at higher power showing the distribution of prekeratin and actin $(\times 750)$. late membranes was $34 \%( \pm 2 \cdot 6 \%)$. There was no significant difference between these two groups by Student's $t$ test $(\mathrm{p}>0 \cdot 05)$.

\section{Discussion}

The features and growth characteristics of ERMs in culture confirmed the findings of a previous report from our laboratory. ${ }^{7}$ Membranes with a clinical age of less than four months (described as early ERMs) had a greater propensity to grow, and to grow after a shorter latent period, than late ERMs (i.e., those of over four months' clinical duration). That late ERMs contain fewer cells and more collagen ${ }^{913}$ than early ERMs would in part help to explain the initial poor performance of the former. However, it should also be borne in mind that, even when growing, the cells of late ERMs were less exuberant than those of early ERMs. Thus it would seem likely that in the culture conditions we established the cells of late ERMs have a diminished potential for replication.

The cells which grew out from our ERM explants varied greatly in morphology (confirming previous reports $^{a-s}$ and reflecting in part their polyphyletic composition). ${ }^{1-5}$ They also showed great variability in the amount of cytoplasmic actin as indicated by microfilaments on electron microscopy and by antiactin immunofluorescence. This study also confirmed the variability of actin staining of cells within excised ERMs. ${ }^{914}$ However, to what extent the content and distribution of actin in the cultured cells reflected that of the ERM cells from which they derived is uncertain. Prominent actin immunostaining has been shown to be a feature of the growing edge of rabbit skin fibroblasts in tissue culture and during the early migratory phase after intravitreal fibroblast injection. ${ }^{15}$

Exposure of cells to either glycerin or non-ionic 


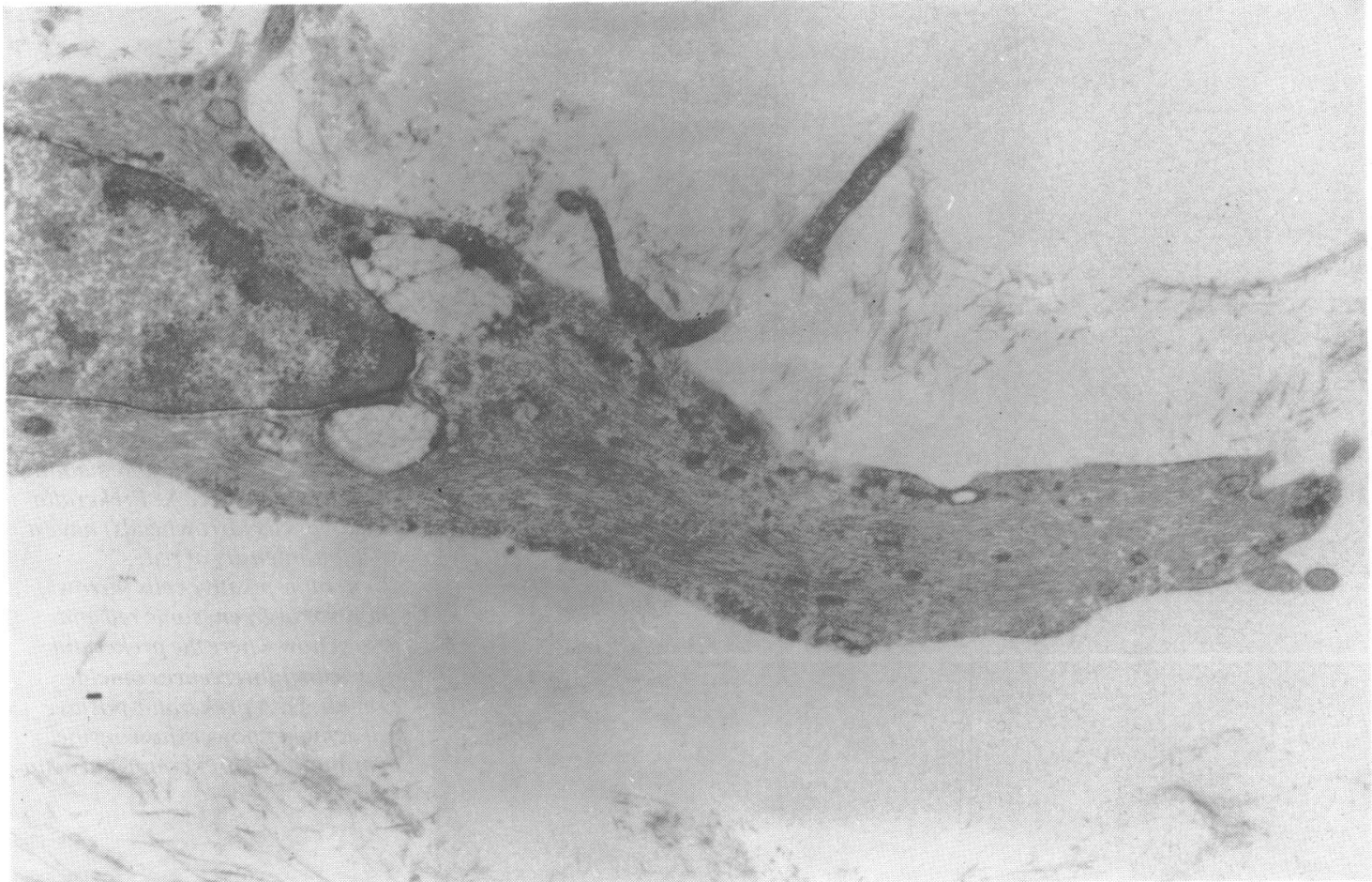

Fig. $7 \quad$ A cell in an ERM explant with prominent microfilaments in the cytoplasm as seen by transmission electron microscopy. $\times 15000$.

detergents opens up cells and removes cytoplasmic constituents but leaves behind cytoplasmic filaments and the nucleus; these cell remnants are often referred to as cytoskeletons..$^{1617}$ If the extraction procedure is conducted in a suitable buffer, then most of the contractile elements can be preserved. ${ }^{12}$
The glycerin or detergent prepared cytoskeletons are freely permeable to electrolytes, drugs, and other chemicals. Indeed, the cytoskeletal preparations from a variety of cells (including amoebae, neutrophils, and fibroblasts) will decrease their surface area after exposure to ATP. ${ }^{1218-20}$ The decrease in surface
Fig. 8 Area change of some intact cells from an ERM during ATP assay. A: The cells before adding ATP. B: The same cells after exposure to ATP for one hour. $\times 300$.

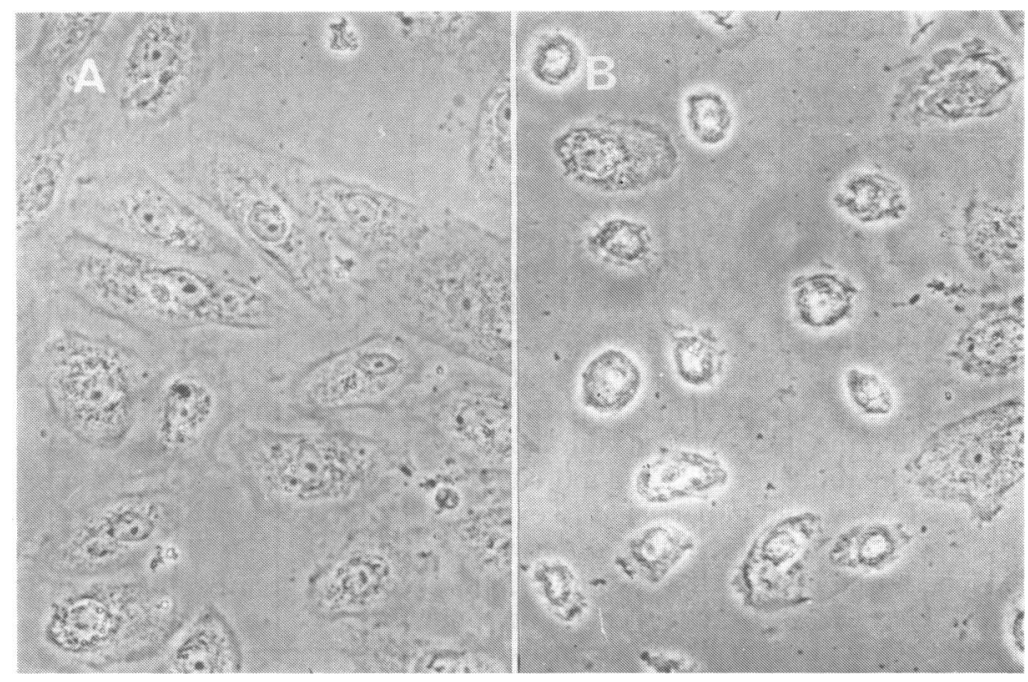




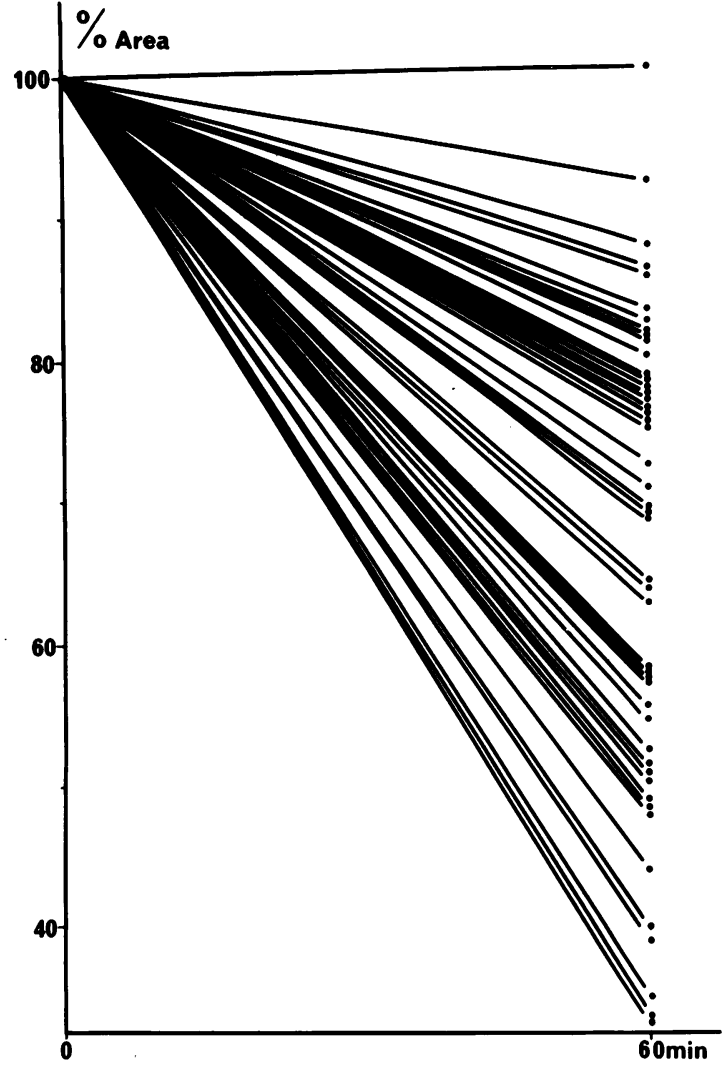

Fig. 9 Variation in response of 44 detergent treated cells after one hour's exposure to 0.1 mM ATP.

area is thought to be an actomyosin-based contractile event $^{1219}$ comparable to the response which can be evoked in muscle fibres subjected to similar treatments.

That ERM cells contract when exposed to ATP has recently been shown by Yamashita and colleagues, ${ }^{14}$ who used a glycerination procedure to produce cytoskeletons. We opted for Triton X-100 because glycerin treatment loosens the attachment of cells to the substrate much more than detergent treatment, ${ }^{121}$ precluding subsequent immunostaining for actin or prekeratin. Glycerinated cytoskeletons also have the disadvantage that on contraction there is structural fragmentation so that the contraction is irreversible. ${ }^{19}$ The Triton X-100 treated cytoskeletons decreased in area by some $30 \%$ in response to ATP over a period of one hour. Although most of the response took place in the first 10 minutes, the contraction was slower and less pronounced than that associated with glycerinated cytoskeletons $^{14}$ of ERM cells exposed to 30 times the concentration of ATP used in this study.

We were surprised to find that intact ERM cells (i.e., cells not exposed to detergent) also produced an average $34 \%$ reduction in area when exposed to ATP. It has generally been considered that glycerination or detergent treatment is a necessary prerequisite for an effective ATP response. Burridge $^{22}$ has emphasised the fact that cultured cells are generally strongly adherent to a rigid substrate (glass or plastic) and in such a condition can only express isometric forces; and furthermore that isotonic contraction will take place only if the cellular adhesion to the rigid culture plate is weakened by exposure to glycerin or detergent. ${ }^{22}$ Certainly, cells well established in culture conditions (having been through several subcultures) are extremely adherent to their substrate; the tightly adherent cells have stress fibres (which are thick bundles of actin-rich microfilaments) and a well spread and flattened morphology. ${ }^{22}$ The ERM cells of the present study were likely to be poorly adherent, being in primary culture and having only recently proliferated from the explant. Indeed our cells were relatively small and not flattened; for example, the prekeratinpositive cells had a surface area which was one-third that of fifth-passage cultured human retinal pigment epithelium (Boulton $\mathbf{M}$, personal communication). Antiactin staining of the ERM cells showed a reticu-

Table 3 Area change produced in detergent treated ERM cells by $0 \cdot 1$ mM ATP

\begin{tabular}{|c|c|c|c|c|c|}
\hline Cell type & No. of cells & Exposure time (minutes) & $\begin{array}{l}\left.\text { Area of cells (in } \mu m^{2}\right) \\
\text { (mean } \pm \text { SEM })\end{array}$ & $\begin{array}{l}\text { \% of original area } \\
(\text { mean } \pm S E M)\end{array}$ & $\begin{array}{l}\text { Paired } \\
\text { ttest }\end{array}$ \\
\hline Prekeratin-positive & 26 & $\begin{array}{r}0 \\
10 \\
60\end{array}$ & $\begin{array}{l}224 \cdot 7 \pm 20 \cdot 9 \\
180 \cdot 6 \pm 17 \cdot 3 \\
158 \cdot 5 \pm 14 \cdot 8\end{array}$ & $\begin{array}{l}100 \\
80 \cdot 3 \pm 2 \cdot 2 \\
70 \cdot 6 \pm 2 \cdot 4\end{array}$ & $\begin{array}{l}\overline{<0.001} \\
<0.001\end{array}$ \\
\hline Prekeratin-negative & 11 & $\begin{array}{r}0 \\
10 \\
60\end{array}$ & $\begin{array}{l}201 \cdot 2 \pm 26 \cdot 5 \\
162 \cdot 7 \pm 20 \cdot 3 \\
143 \cdot 5 \pm 19 \cdot 1\end{array}$ & $\begin{array}{l}100 \\
80 \cdot 9 \pm 3 \cdot 7 \\
71 \cdot 4+3 \cdot 1\end{array}$ & $\begin{array}{l}-\overline{-} \\
<0.01 \\
<0.01\end{array}$ \\
\hline Unidentified & 7 & $\begin{array}{r}0 \\
10 \\
60\end{array}$ & $\begin{array}{l}341 \cdot 4 \pm 54 \cdot 2 \\
251 \cdot 9 \pm 37 \cdot 8 \\
223 \cdot 8 \pm 40 \cdot 9\end{array}$ & $\begin{array}{l}100 \\
73 \cdot 8 \pm 5 \cdot 6 \\
65 \cdot 6 \pm 6 \cdot 9\end{array}$ & $\begin{array}{l}-\overline{-} \\
<0.05 \\
<0.05\end{array}$ \\
\hline All cells & 44 & $\begin{array}{r}0 \\
10 \\
60\end{array}$ & $\begin{array}{l}237 \cdot 4 \pm 17 \cdot 5 \\
186 \cdot 9 \pm 13 \cdot 4 \\
164 \cdot 8 \pm 12 \cdot 3\end{array}$ & $\begin{array}{l}100 \\
78 \cdot 7 \pm 3 \cdot 7 \\
69 \cdot 4 \pm 1 \cdot 9\end{array}$ & $\begin{array}{l}<\overline{-} \\
<0.001 \\
<0.001\end{array}$ \\
\hline
\end{tabular}



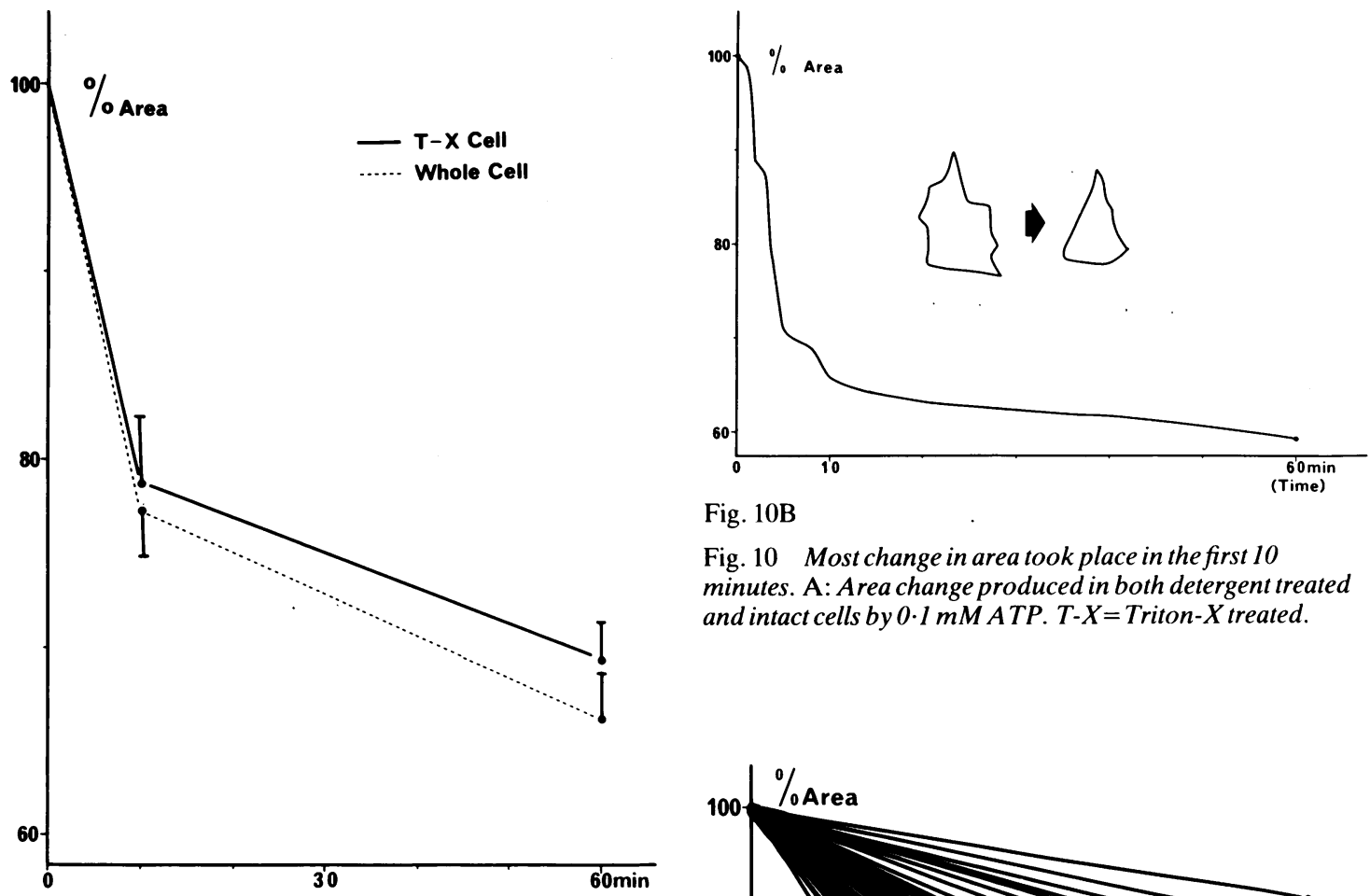

Fig. 10B

Fig. 10 Most change in area took place in the first 10 minutes. A: Area change produced in both detergent treated and intact cells by $0 \cdot 1 \mathrm{mM} A T P$. $T-X=$ Triton- $X$ treated.
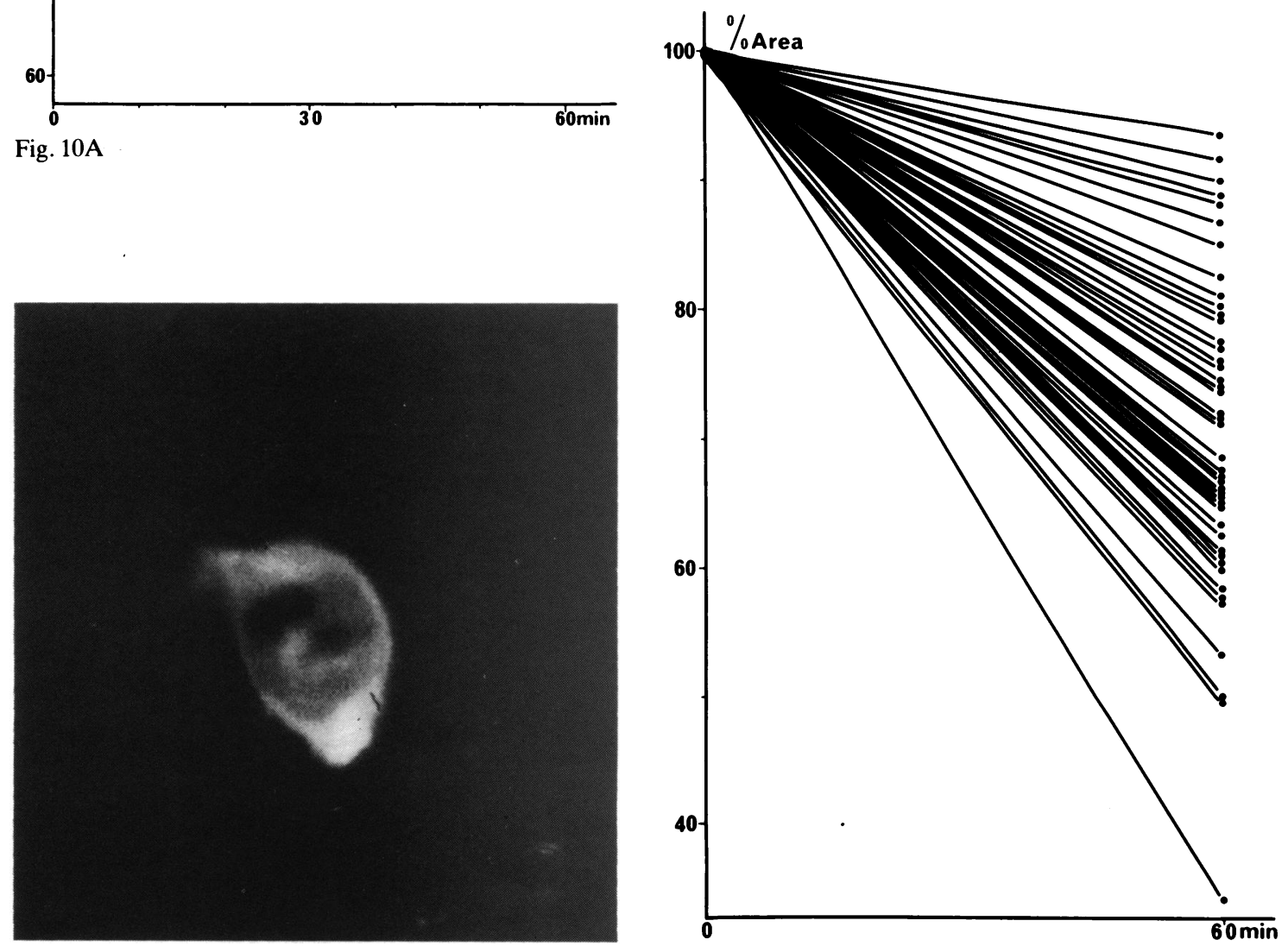

Fig. 11 A prekeratin-positive ERM cell after detergent treatment and ATP assay $($ FOTC). $\times 800$.

Fig. 12 Variation in response of 47 intact cells after one hour's exposure to $0.1 \mathrm{mM}$ ATP. 
Table 4 Areachange produced in intact ERM cells by $0.1 \mathrm{mM}$ ATP

\begin{tabular}{|c|c|c|c|c|c|}
\hline Cell type & No. of cells & Exposure time (minutes) & $\begin{array}{l}\left.\text { Area of cells (in } \mu m^{2}\right) \\
\text { (mean } \pm S E M)\end{array}$ & $\begin{array}{l}\% \text { of original area } \\
\text { (mean } \pm S E M)\end{array}$ & $\begin{array}{l}\text { Paired } \\
\text { t test }\end{array}$ \\
\hline \multirow[t]{3}{*}{ Prekeratin-positive } & \multirow[t]{3}{*}{18} & 0 & $379 \cdot 4 \pm 91 \cdot 6$ & 100 & - \\
\hline & & 10 & $306 \cdot 3 \pm 79 \cdot 9$ & $79 \cdot 3 \pm 3 \cdot 8$ & $<0.001$ \\
\hline & & 60 & $284.5 \pm 78.9$ & $70 \cdot 8 \pm 3 \cdot 9$ & $<0.001$ \\
\hline \multirow[t]{3}{*}{ Prekeratin-negative } & \multirow[t]{3}{*}{9} & 0 & $317 \cdot 7 \pm 71 \cdot 6$ & 100 & - \\
\hline & & 10 & $250 \cdot 7 \pm 68 \cdot 7$ & $75 \cdot 8 \pm 6 \cdot 3$ & $<0.01$ \\
\hline & & 60 & $213.9 \pm 69.5$ & $58 \cdot 6 \pm 7 \cdot 2$ & $<0.01$ \\
\hline \multirow[t]{3}{*}{ Unidentified } & \multirow[t]{3}{*}{20} & 0 & $379 \cdot 3 \pm 59 \cdot 1$ & 100 & - \\
\hline & & 10 & $306 \cdot 9 \pm 54 \cdot 3$ & $76 \cdot 3 \pm 3 \cdot 6$ & $<0.001$ \\
\hline & & 60 & $263 \cdot 3 \pm 48 \cdot 8$ & $65 \cdot 5 \pm 3 \cdot 5$ & $<0.001$ \\
\hline \multirow[t]{3}{*}{ All cells } & \multirow[t]{3}{*}{47} & 0 & $367 \cdot 5 \pm 44 \cdot 6$ & 100 & - \\
\hline & & 10 & $295.9 \pm 39.9$ & $77 \cdot 3 \pm 2 \cdot 4$ & $<0.001$ \\
\hline & & 60 & $261 \cdot 9 \pm 38 \cdot 4$ & $66 \cdot 2 \pm 2 \cdot 5$ & $<0.001$ \\
\hline
\end{tabular}

lar pattern in the cytoplasm of some cells, but the fine threads of actin-positive fluorescence were not stress fibres; stress fibres are much thicker structures. ${ }^{17}$ Their small size and the absence of stress fibres would make it unlikely that ERM cells had particularly tenacious attachments and in part helps to explain their ability to respond to ATP. Detailed investigation is required before the ATP contraction associated with intact ERM cells in primary culture is fully understood. Nevertheless there are distinct advantages in working with intact cells; for example, there is no possibility of elution of contractile elements, and the outline of an intact cell is far easier to measure than that of a cytoskeleton during the ATP assay.

A total of 91 intact cells and cytoskeletons were analysed during ATP exposure and all but one contracted to some extent. The variation in response between cells or their cytoskeletons was so pronounced that we suspected that this was related to the different clinical ages of ERMs or to cell type. However, immunostaining for cytokeratins (after the contraction run) showed that the response of epithelial cells was just as wide ranging as that of the non-epithelial cells. Given the similarity of response of intact epithelial cells and epithelial cytoskeletons, it is unlikely we were dealing with an artefact relating to assaying procedures. More probably we were dealing with differences in the cells metabolism or behaviour at the time of assay. In particular the organisation and amount of actin appeared to vary in both the epithelial and non-epithelial groups of cells.

This is the first demonstration that ERM-derived cells which are undoubtedly epithelial can contract. Since the early work of Machemer ${ }^{223}$ retinal pigment epithelial cells have been especially implicated in the formation and tractional activities of ERMs. However, the contraction of epithelial cells was no greater than that of other cells in our ERMs supporting our view, expressed elsewhere, ${ }^{524}$ that the role of retinal pigment epithelial cells has perhaps been overemphasised. Our histochemistry, following the ATP assay, showed that 44 out of 64 cells were prekeratin-positive. This high proportion of epithelial cells may reflect their preferential growth in our culture conditions, or preferential selection for assay because of their clearly defined borders and contact inhibition, ${ }^{7}$ rather than their prevalence in situ.

We hope that the single cell assay can be used in future for further evaluation of the contractility of the different types of cell which can be grown from epiretinal membranes. It is intended that our assay be used to evaluate smooth muscle relaxant drugs which may have a role in controlling tractional activity in situ.

This work has been supported by the Wellcome Trust (grant no. 10998/1.5) and in part by the TFC Frost Charity Trust. We thank Mr P K Leaver, Mr R J Cooling, and Mr Z Gregor, who provided many of the specimens, and Mrs P Goodwin for secretarial assistance.

\section{References}

1 Van Horn DL, Aaberg TM, Machemer R. Glial cell proliferation in human retinal detachment with massive periretinal proliferation. Am J Ophthalmol 1977; 84:383-93.

2 Machemer R, Van Horn DL, Aaberg TM. Pigment epithelial proliferation in human retinal detachment with massive periretinal proliferation. Am J Ophthalmol 1978; 85: 181-91.

3 Kampik A, Kenyon KR, Michels RG, Green WR, de la Cruz ZC. Epiretinal and vitreous membranes: comparative study of 56 cases. Arch Ophthalmol 1981; 99: 1445-54.

4 Hiscott PS, Grierson I, Trombetta CJ, Rahi AHS, Marshall J McLeod D. Retinal and epiretinal glia: an immunohistochemical study. Br J Ophthalmol 1984; 68: 698-707.

5 Hiscott PS, Grierson I, McLeod D. Retinal pigment epithelial cells in epiretinal membranes: an immunohistochemical study. BrJ Ophthalmol 1984; 68: 708-15.

6 Newsome DA, Rodrigues MM, Machemer R. Human massive periretinal proliferation: in vitro characteristics of cellular components. Arch Ophthalmol 1981; 99: 873-80.

7 Hiscott PS, Grierson I, Hitchins CA, Rahi AHS, McLeod D. Epiretinal membranes in vitro. Trans Ophthalmol Soc UK 1983; 103: 89-102. 
8 Yamashita H, Hori S, Kitano S, Ishii Y, Masuda K. Glial cells in culture of preretinal membrane of proliferative vitreoretinopathy. Jpn J Ophthalmol 1985; 29: 42-53.

9 Hiscott PS, Grierson I, McLeod D. Natural history of fibrocellular epiretinal membranes: a quantitative, autoradiographic and immunohistochemical study. $\mathrm{Br} J$ Ophthalmol 1985; 69: 810-23.

10) Gabbiani G, Ryan GB, Majno G. Presence of modified fibroblasts in granulation tissue and their possible role in wound contraction. Experimentia 1971; 15: 549-50.

11 Gabbiani G, Hirschel BJ, Ryan GB, Statkov PR, Majno G Granulation tissue as a contractile organ: a study of structure and function. J Exp Med 1972; 135: 719-34.

12 Masuda H, Owaribe K, Hatano S. Contraction of triton-treated culture cells. Exp Cell Res 1983; 143: 79-90.

13 Constable IL, Tolentino FI, Donovan RH, Schepens CL. Clinicopathologic correlation of vitreous membranes. In: Pruett RC, Regan CDJ, eds. Retina congress. New York: AppletonCentury-Crofts, 1974: 245-57.

14 Yamashita H, Hori S, Masuda K. Microfilaments in preretinal membrane cells of proliferative vitreoretinopathy. Jpn J Ophthalmol 1985; 29: 394-405.

15 Grierson I, Rahi AHS. Structural basis of contraction in vitreal fibrous membranes. Br J Ophthalmol 1981; 65: 737-49.

16 Osborn M, Weber K. The detergent-resistant cytoskeleton of tissue culture cells includes the nucleus and the microfilament bundles. Exp Cell Res 1977; 106: 339-49.
17 Kries TE, Birchmeier W. Stress fiber sarcomeres of fibroblasts are contractile. Cell 1980; 22: 555-61.

18 Simard-Duquesne N, Coulliard P. Amoeboid movement I: reactivation of glycerinated models of amocba proteins with adenosine triphosphate. Exp Cell Res 1962; 28: 85-91.

19 Norberg B. Amocboid movements and cytoplasmic fragmentation of glycerinated leukocytes induced by ATP. Exp Cell Res 1970; 59: 11-21.

20 Hsu LS, Becker EL. Volume decrease of glycerinated polymorphonuclear leukocytes induced by ATP and $\mathrm{Ca} 2+$. Exp Cell Res 1975; 91: 469-73.

21 Grierson I, Millar LC, Jiang DY, et al. Anatomical and functional investigations of cytoskeletal elements in cultured bovine meshwork cells. Invest Ophthalmol Vis Sci 1986; 27: 1318-30.

22 Burridge K. Are stress fibres contractile? Nature 1981; 294: 691-2.

23 Machemer $\mathrm{R}$, Laqua $\mathrm{H}$. Pigment epithelial proliferation in retinal detachment (massive periretinal proliferation). Am J Ophthalmol 1975; 80: 1-23.

24 McLeod D. Hiscott PS, Grierson I. Age-related cellular proliferation at the vitreoretinal juncture. Eye 1987; 1: 263-81.

Accepted for publication 15 December 1986. 